\title{
Resolving Chilean dolphin (Cephalorhynchus eutropia, Gray 1846) synonymy by sequencing DNA extracted from teeth of museum specimens
}

\author{
Resolviendo la sinonímia del delfín Chileno (Cephalorhynchus eutropia, Gray 1846) \\ mediante secuenciamiento de ADN extraído desde dientes \\ de especímenes de museo
}

Franz B. Pichler and Carlos Olavarría B.

University of Auckland, School of Biological Sciences. Private Bag 92019, Auckland, New Zealand. f.pichler@auckland.ac.nz

\begin{abstract}
Mitochondrial DNA was amplified and sequenced from single teeth of six museum specimens described by Phillipi (1893) as three novel species, Phocoena albiventris, Tursio platyrhinus and T. panope. Subsequently, these specimens were reviewed and, with the exception of $T$. panope, were suggested as probable specimens of Chilean dolphin, Cephalorhynchus eutropia. DNA sequence from five of the six samples were compared to an existing database of odontocete type-sequences. These confirm that the specimens were Chilean dolphins. We conclude that T. panope is a Chilean dolphin, albeit of unusual size. These results demonstrate the utility of genetic testing of museum specimens to help resolve uncertainty in species identification. Palabras Claves: Delfín chileno, especímenes de museo, taxonomía, ADNmt
\end{abstract}

Resumen .- Se amplificó y secuenció ADN mitocondrial a partir de muestras dentarias de seis especímenes de museo descritos por Phillipi (1893) como especies nuevas, Phocoena albiventris, Tursio platyrhinus y T. panope. Estos especímenes fueron revisados con posterioridad y, con la excepción de $T$. panope, fueron reidentificados como probables delfín Chileno, Cephalorhynchus eutropia. Secuencias de ADN de cinco de las seis muestras fueron comparadas con una base de datos existente de secuencias tipo de odontocetos. Esta comparación confirma que los especímenes corresponden a delfin Chileno. Por lo tanto, T. panope es un delfín Chileno, aunque de inusual tamaño. Estos resultados demuestran la utilidad de análisis genéticos en especímenes de museo para ayudar a resolver ambiguedades en la identificación a nivel específico.

Key words: Chilean dolphin, museum specimens, taxonomy, mtDNA
The classification of the Chilean dolphin (Cephalorhynchus eutropia, Gray 1846), based on a single skull (BMNH 936a) and without a physical description, resulted in considerably synonomy and confusion over the identity of museum specimens (as reviewed in Goodall et al. 1988). Based on a description of a dolphin caught in Valparaíso, Chile in 1882, Philippi (1893) proposed a new species Phocaena (or later: Tursio) albiventris. He subsequently examined several skulls from within Chilean waters some which he assigned to his proposed species (T. albiventris). Based on morphological variation between these skulls also he proposed a further two species, T. platyrrhinus (Philippi 1893) and Turiso panope. In his review of the skulls of Chilean dolphins, Philippi (1896) provided illustrations (Plates IV - VI) that appear to show significant morphological differences between skulls representing the three proposed species of dolphin
(Philippi 1893). However, True (1903) suggested that the three species described by Philippi were Chilean dolphins. Using measurements of the same skulls made by RL Brownell Jr in 1973, Goodall \& Cameron (1979) concurred with True that both $P$. albiventris and $T$. platyrrhinus were Chilean dolphins. As the condylobasal length of the type skull of $T$. panope (MNHM-S 584) was larger (at 379mm) than that found in Chilean dolphins (302 - 364mm), Goodall \& Cameron (1979) suggested that the classification of this specimen could not be determined. Later examinations of the skull of T. panope (Brownell \& Mead 1989, Van Waerebeek 1992) suggested that the specimen was a dusky dolphin, Lagenorhynchus obscurus. However, at the initiation of this study the identity of the $T$. panope skull was still uncertain, requiring further investigation. 
Specimens of cetaceans that are held in museum collections contain DNA that can be used to provide significant insights into species identification (e.g. Dalebout et al. in review) and historic genetic structure (e.g. Rosenbaum et al. 1997, Pichler \& Baker 2000). Depending on the treatment and storage of the specimen, bones (Dizon et al. 1995), baleen plates (Kimura et al. 1997, Rosenbaum et al. 1997) and particularly teeth (Pichler \& Baker 2000) have been found to provide adequate DNA for genetic analyses. Only modest amounts of material are required from the specimen, such as single teeth from small odontocetes (Pichler \& Baker 2000) or powder from holes drilled in the skull or teeth of larger cetaceans (Pichler et al. in review, Dalebout et al. in review). Here we attempt to identify the species of each of ten individual specimens, from museum collections in Chile, including six representatives of the three species described by Philippi (1893).

To preserve the maximum amount of museum material, a single tooth of each specimen (Table 1) was collected. Prior to freezing the tooth (in liquid nitrogen or at $-80^{\circ} \mathrm{C}$ overnight), the exterior surface of each tooth was lightly sanded to remove potential surface contaminants. The tooth was then placed into a sterile tooth-crushing device and reduced to fine powder (Pichler \& Baker 2000). DNA was extracted from this powder (< $1 \mathrm{~g}$ in weight) using a modified silica extraction procedure (Boom et al. 1990, Matisoo-Smith et al. 1997) as described in Pichler \& Baker (2000). Sterile conditions and disposable equipment were used to minimise risk of contamination.

A 550 base pair (bp) region of the mitochondrial (mt) DNA control region was amplified by Polymerase Chain Reaction (PCR, Saiki et al. 1988) with primers dlp1.5 (5’ - TCA CCC AAA GCT GRA RTT CTA - 3’) and dlp5 (5'- CCA TCG WGA TGT CTT ATT TAA GRG GAA - 3') following Pichler \& Baker (2000). If this fragment failed to amplify, primer dlp5 was replaced with dlp4 (5'-CGG GTT GCT GGT TTC ACG-3') for amplification of a 400bp fragment. Finally, if both of these amplifications failed, a short 200 bp fragment was amplified using primers dlpFBP (5'-GTA CAT GCT ATG TAT TAT TGT GC-3') to dlp4. The PCR was prepared using dedicated "pre-PCR" pipettors with barrier tips, surfaces that had never been exposed to DNA extracts or PCR products and new reagents. The PCR amplicon was quantified using gel electrophoresis with DNA low-mass ladder (GIBCO BRL) then sequenced using BigDye (Applied Biosystems) chemistry and electrophoresed on an ABI 377 autosequencer.

Sequences of sufficient quality to determine species identification were obtained from a total of nine of the ten museum specimens. Successful amplification of 550 bp fragments was achieved from four of the samples. From the remaining five samples, two yielded 400 bp fragments and three yielded 200 bp fragments. The mtDNA "test" sequences obtained from the museum specimens were aligned by eye to a database of cetacean reference sequences (Baker et al. 1996) to confirm that the test sequences were Delphinids. The sequences were then imported into a database including representatives of 18 Delphinid species (unpublished data). The phylogeny of the Delphinids were reconstructed in PAUP v4.02b (Swofford 1998) using heuristic parsimony and including one test sequence at a time to establish the species identity of that sequence. A test sequence that fell within the clade of sequences representative of one species was considered to represent another individual from that species.

Using this method, all nine specimens for which we obtained sequences, including the type of Tursio panope, were identified as Chilean dolphins. No sequence differed from the nine existing Chilean dolphin sequence types, obtained from 13 beachcast Chilean dolphins, by more than two substitutions. Further, each sequence had an indel, at position "99" relative to the first bp of the control region, characteristic of the genus Cephalorhynchus, and of the same length found only in the Chilean and Commerson's dolphin (C. commersonii, unpublished data). The exact Chilean dolphin haplotype of seven of the nine sequences was determined despite four of the sequences being short fragments (Table 2). The sequence of Tursio panope was also short (200 bp), resulting in an incomplete fragment that allowed unequivocal identification of the species of the sample, but not to the precise haplotype.

The genetic evidence presented here confirm the morphological examinations of True (1903) and Goodall \& Cameron (1979) that $P$. albiventris and $T$. platyrrhinus are junior synonyms of $C$. eutropia. Further, mtDNA sequence from the type specimen of $T$. panope supports True's (1903) suggestion that this skull was in fact a Chilean dolphin and not a dusky dolphin (Brownell \& Mead 1989, Van Waerebeek 1992) or a new species (Philippi 1893). These results show that the three species proposed by Philippi arose from his difficulty in interpreting Gray's vague descriptions (Philippi 1896). Goodall et al. (1988) report that, due to damage to the type skull of $T$. panope, their measurement of the condylobasal length is an underestimate. Our finding that this skull was from a Chilean dolphin indicates that the skull may be the largest recorded for this species.

This report demonstrates the utility of genetic analysis in helping to resolve, or confirm, taxonomic 
status of museum specimens. In the case of damaged or partial specimens, genetic identification may be the only method for determination of the species of origin for these materials. Museum collections are an invaluable resource of material for natural history studies. In particular, where a species is poorly known due to its rare or elusive nature in the wild, museum collections accrued over decades can help uncover answers to the taxonomy and current status of these species.

\section{Table 1}

Specimen codes and species identification of the ten specimens examined. The two codes refer to the classification given to the species post identification at the University of Auckland (AUNZ) and the code attached to the specimen at the museum collection (CZI = Colección Zoología Instituto de la Patagonia, Punta Aremas, Chile; MNHN-S = Museo Nacional de Historia Natural de Santiago, Chile). The dates are as recorded on the specimens or as given in Goodall et al (1988). Otherwise dates are given as prior to the first reference of the specimen in a publication or report. The original classification of the specimen is given along with the subsequent DNA species identification. The haplotype of the specimen is noted in the final column. Novel haplotypes are shown in bold.

Código e identificación específica de los diez especímenes examinados. Los dos códigos se refieren a la clasificación dada a las especies luego de la identificación en la University of Auckland (AUNZ) y al código original en los museos (CZI = Colección Zoología Instituto de la Patagonia, Punta Aremas, Chile; MNHN-S = Museo Nacional de Historia Natural de Santiago, Chile). Las fechas son aquellas registradas en los especímenes o aquellos dados por Goodall et al (1988). De otra manera, las fechas se refieren a aquellas de la primera referencia hecha para el especimen en una publicación o reporte. La clasificación original de los especímenes está dada luego de la identificación mediante ADN. El haplotipo de los especímenes está anotado en la columna final. Nuevos haplotipos están mostrados en negrita.

\begin{tabular}{|c|c|c|c|c|c|}
\hline \multicolumn{2}{|r|}{ Code } & \multirow[b]{2}{*}{ Date } & \multirow[b]{2}{*}{ Original classification } & \multirow[b]{2}{*}{ DNA identification } & \multirow[b]{2}{*}{ Haplotype } \\
\hline AUNZ & Museum & & & & \\
\hline Ceut10 & CZIP0529 & $?$ & C. eutropia & C. eutropia & A \\
\hline Ceut11 & MNHN-S 581 & $<1904$ & Phocaena albiventris & C. eutropia & $\mathbf{J}$ \\
\hline Ceut12 & MNHN-S 582 & $<1886$ & Phocaena albiventris “dibujado" & C. eutropia & I \\
\hline Ceut13 & MNHN-S 583 & $<1893$ & Phocaena albiventris & C. eutropia & $\mathbf{K}$ \\
\hline Ceut14 & MNHN-S 584 & 1887 & Tursio panope Philippi & C. eutropia & $\mathrm{A}$ or $\mathrm{B}$ \\
\hline Ceut15 & MNHN-S 585 & 1882 & Tursio albiventris Perez (1893) & C. eutropia & $\mathrm{D}$ or $\mathrm{E}$ \\
\hline Ceut16 & MNHN-S 587 & 1894 & Tursio platyrrhinus “dibujado” & fail & Fail \\
\hline Ceut17 & MNHN-S 592 & $<1904$ & C. eutropia & C. eutropia & $\mathbf{L}$ \\
\hline Ceut18 & MNHN-S 594 & $<1978$ & C. eutropia & C. eutropia & $\mathbf{L}$ \\
\hline Ceut19 & MNHN-S 1493 & $?$ & $?$ & C. eutropia & $\mathbf{M}$ \\
\hline
\end{tabular}

Specimen information for Philippi's skulls.:

MNHN-S 581 Phocaena albiventris, collected at Chiloé $\left(42^{\circ} \mathrm{S} ; 74^{\circ} \mathrm{W}\right)$ by the 1880 's.

MNHN-S 583 Phocaena albirostris and Tursio albiventris, collected at Talcahuano (36² $40^{\prime}$ S; $\left.73^{\circ} 10^{\prime} \mathrm{W}\right)$ by $1880^{\prime}$ 's.

MNHN-S 582: The skull illustrated in Philippi 1896.

MNHN-S 584: type of Tursio panope.

MNHN-S 585, Tursio albiventris collected at Río Valdivia (3950'S; $73^{\circ} 25^{\prime} \mathrm{W}$ ) or Valparaíso (3300'S; $\left.71^{\circ} 35^{\prime} \mathrm{W}\right)$ in 1882. 
Table 2

Comparison of mitochondrial haplotypes obtained from Chilean dolphin specimens (n=13) with the test sequences from the museum samples. The consensus fragment begins at position 15 relative to the first base pair of the mtDNA control region. The numbering of sites of substitutions is relative to the first base pair of the t-pro end of the control region. There are two gaps (not shown) when aligned to all Delphinids, the first gap extends from position 85 to 101 and the second from 109 to 111. These gaps are identical in length to that of the outgroup but no other species.

Comparación de los haplotipos mitocondriales obtenidos de especímenes de delfines Chilenos (n=13) con las secuencias de referencia obtenidas de muestras de museo. El fragmento consenso comienza en la posición 15 relativa a la primera base de la región control del ADN mitocondrial. El número de los sitios de sustitución es relativo al rpimer par de bases del extremo t-pro de la región control. Existen dos inserciones (no mostrado) al alinear esta secuencias con aquellas de los demás delfínidos, el primero se extiende desde la posición 85 a 101 y la segunda desde la posición 109 a la 111. Esas inserciones son idénticas en longitud a aquella del outgroup pero no a otras especies.

\begin{tabular}{|c|c|c|c|c|c|c|c|c|c|c|}
\hline Haplotype & Length & 42 & 56 & 252 & 239 & 297 & 349 & 352 & 396 & 482 \\
\hline A & 550 & A & A & $\mathrm{T}$ & $\mathrm{T}$ & $\mathrm{T}$ & G & A & $\mathrm{T}$ & $\mathrm{T}$ \\
\hline B & 550 & . & . & . & . & . & . & . & $\mathrm{C}$ & . \\
\hline $\mathrm{C}$ & 550 & . & . & . & . & $\mathrm{C}$ & . & . & $\mathrm{C}$ & $\mathrm{C}$ \\
\hline $\mathrm{D}$ & 550 & . & . & G & . & . & . & . & . & . \\
\hline $\mathrm{E}$ & 550 & . & . & G & . & . & . & . & . & $\mathrm{C}$ \\
\hline $\mathrm{F}$ & 550 & . & . & G & $\mathrm{C}$ & . & . & . & . & . \\
\hline G & 550 & . & . & G & $\mathrm{C}$ & . & . & . & . & . \\
\hline $\mathrm{H}$ & 550 & . & . & G & $\mathrm{C}$ & . & . & $\mathrm{T}$ & . & . \\
\hline I & 550 & . & . & . & . & . & . & $\mathrm{T}$ & . & . \\
\hline Ceut10 & 550 & . & . & . & . & . & . & . & . & . \\
\hline Ceut11 & 550 & G & G & . & . & . & . & . & . & . \\
\hline Ceut12 & 200 & $?$ & $?$ & . & . & . & . & $\mathrm{T}$ & $?$ & $?$ \\
\hline Ceut13 & 400 & . & . & G & $\mathrm{C}$ & . & A & $\mathrm{T}$ & $?$ & ? \\
\hline Ceut14 & 200 & $?$ & ? & . & . & . & . & . & $?$ & $?$ \\
\hline Ceut15 & 200 & ? & ? & G & . & . & $?$ & $?$ & $?$ & $?$ \\
\hline Ceut17 & 400 & . & . & . & . & . & . & . & . & C \\
\hline Ceut18 & 550 & . & . & . & . & . & . & . & . & C \\
\hline Ceut19 & 550 & . & . & . & . & . & . & . & $\mathrm{C}$ & $\mathrm{C}$ \\
\hline
\end{tabular}

\section{Acknowledgments}

We are grateful with José Yañez, curator of the cetacean collection of Museo Nacional de Historia Natural of Santiago, Chile and Jorge Gibbons of Instituto de la Patagonia, Punta Arenas for their generosity in provide us access to the specimens of their institutional collections. Sample teeth were exported under CITES permit 04/98, extended by the Servicio Nacional de Pesca de Chile. We thank Nathalie Patenaude for comments on the manuscript. Alfonso Olavarría and NZ Marsden Foundation provided funding for this work.

\section{Literature cited}

Baker CS, F Cipriano \& SR Palumbi. 1996. Molecular genetic identification of whale and dolphin products from commercial markets in Korea and Japan. Molecular Ecology 5: 671-685.

Boom R, CJA Sol, CL Jansen, PME Wertherim-van Dillen \& J van der Noorda. 1990. Rapid and simple method for purification of nucleic acids. Journal of Clinical Microbiology 28: 495-503.

Brownell Jr. RL \& JG Mead. 1989. Taxonomic status of the delphinid (Mammalia: Cetacea) Tursio? panope Philippi, 1895. Proceedings of the Biological Society of Washington 102(2): 532-534.

Dalebout ML, JG Mead, K Van Waerebeek, JC Reyes, VG Cockcroft \& CS Baker. (in review). Molecular discovery and cryptic morphology of new beaked whale species. 
Dizon AE, CA Lux, RG LeDuc, J Urban-Ramirez, M Henshaw \& RL Brownell. 1995. An interim phylogenetic analysis of sei and Bryde's whale mitochondrial DNA control region sequences. Report of the International Whaling Commissionn SC/47/NP/23.

Goodall RNP \& IS Cameron. 1979. Phocoena dioptrica, una nueva especie para aguas Chilenas. Revista Museo Argentino de Ciencias Naturales 'Bernardino Rivadavia', Zoología 12: 143-152.

Goodall RNP, KS Norris, AR Galeazzi, JA Oporto \& IS Cameron. 1988. On the Chilean Dolphin, Cephalorhynchus eutropia (Gray, 1846). In Brownell Jr. RL \& GP Donovam (eds), Biology of the genus Cephalorhynchus: 197-258. Special Issue 9 International Whaling Commission. Cambridge, U.K.

Gray JE. 1846. In J Richardson \& JE Gray (eds..), The zoology of the voyage of the H.M.S. Erebus and Terror, Vol 1. Mammalia: 1844-1875. Birds Janson, London.

Kimura T, T Ozawa \& LA Pastene. 1997. Sample preparation and analysis of mitochondrial DNA from whale baleen plates. Marine Mammal Science 13: 495498.

Matisoo-Smith E, JS Allen, TN Ladefogd, RM Roberts \& DM Lambert. 1997. Ancient DNA from Polynesian rats: extraction, amplification and sequence from single bone. Electrophoresis 18.

Philippi RA. 1893. Los delfines de la punta austral de la América del Sur. Anales del Museo Nacional de Chile. (Zool) 6: 1-17.
Philippi RA. 1896. Los cráneos de los delfines Chilenos. Anales del Museo Nacional de Chile 12: 1-18.

Pichler FB \& CS Baker. 2000. Loss of diversity in the endemic Hector's dolphin due to fisheries-related mortality. Proceedings of the Royal Society of London, Series B 267: 97-102.

Pichler FB, ML Dalebout \& CS Baker. (in review). Nondestructive DNA extraction from sperm whale teeth and scrimshaw.

Rosenbaum HC, MG Egan, PJ Clapham, RL Brownell \& R DeSalle. 1997. An effective method for isolating DNA from historical specimens of baleen. Molecular Ecology 6: 677-681.

Saiki RK, DH Gelfand, S Stoffel, SJ Scharf, R Higuchi, GT Horn, KB Mullis \& HA Erlich. 1988. Primer-directed enzymatic amplification of DNA with a thermostable DNA polymerase. Science 239: 487-491.

Swofford DL. 1998. PAUP*, Phylogenetic analysis using parsimony (* and other methods). Sinauer Associates, Sunderland, Massachusetts.

True FW. 1903. On the species of the South American Delphinidae described by Dr RA Philippi in 1893 and 1896. Proceedings of the Biological Society, Washington, 16: $133-144$

Van Waerebeek K. 1992. Records of dusky dolphins, Lagenorhynchus obscurus (Gray, 1828) in the Eastern South Pacific. Beaufortia 43(4): 45-60. 